Received 00th January 20xx, Accepted 00th January 20xx

DOI: $10.1039 / \times 0 x \times 00000 x$

www.rsc.org/

\title{
Synthesis and Reactivity of Selenium Functionalised Allylidynes and Propargylidynes
}

\author{
Anthony F. Hill*, Richard A. Manzano and Jas S. Ward.
}

The reactions of the trimethylsilylpropargylidyne $\left[\mathrm{W}(\equiv \mathrm{CC} \equiv \mathrm{CSiMe})(\mathrm{CO})_{2}\left(\mathrm{Tp}^{*}\right)\right]\left(\mathbf{1}: \mathrm{Tp}^{*}=\right.$ hydrotris(dimethylpyrazolyl)borate) towards selenium centred reagents when treated with tetrabutylammonium fluoride (TBAF) were explored in order to prepare alkynylselenolato propargylidynes, e.g., $\left[\mathrm{W}(\equiv \mathrm{CC} \equiv \mathrm{CSePh})(\mathrm{CO})_{2}\left(\mathrm{Tp}^{*}\right)\right]$. Treating 1 with TBAF and $\mathrm{PhSeSePh}$ resulted in $E$ and $Z$ isomers of the vinylcarbyne (allylidyne) complex $\left[\mathrm{W}\{\equiv \mathrm{CC}(\mathrm{SePh})=\mathrm{CHSePh}\}(\mathrm{CO})_{2}\left(\mathrm{Tp}^{*}\right)\right]$ in addition to traces of the trisubstituted derivative $\left[\mathrm{W}\left\{\equiv \mathrm{CC}(\mathrm{SePh})=\mathrm{C}(\mathrm{SePh})_{2}\right\}(\mathrm{CO})_{2}\left(\mathrm{Tp}^{*}\right)\right]$. Reactions with $\mathrm{PhSeCl}$ resulted in the isolation of bimetallic bis-substituted allylidyne complex $\left[\left(\mathrm{Tp}^{*}\right)(\mathrm{CO})_{2} \mathrm{~W} \equiv \mathrm{CC}(\mathrm{SePh})=\mathrm{C}(\mathrm{SePh}) \mathrm{C} \equiv \mathrm{CC} \equiv \mathrm{W}(\mathrm{CO})_{2}(\mathrm{CO})_{2}(\mathrm{Tp} *)\right]$ as well as the desired selenolatopropargylidyne $\left[\mathrm{W}(\equiv \mathrm{CC} \equiv \mathrm{CSePh})(\mathrm{CO})_{2}\left(\mathrm{Tp}^{*}\right)\right]$.

\section{Introduction}

Propargylidyne complexes $L_{n} M \equiv C C \equiv C R$ are of interest in that they feature both metal-carbon and carbon-carbon triple bonds in conjugation. ${ }^{1} \quad$ Silylpropargylidynes, e.g., $\left[\mathrm{W}\left(\equiv \mathrm{CC} \equiv \mathrm{CSiMe}_{3}\right)(\mathrm{CO})_{2}\left(\mathrm{Tp}^{*}\right)\right](\mathbf{1})^{1 \mathrm{~b}}$ serve as versatile building blocks for constructing bi- and trimetallic assemblies in which two or more metal centres are bridged by tricarbido linkages. ${ }^{2}$ Thus treatment of $\mathbf{1}$ with fluoride or methoxide results in desilylation to provide a reagent that serves as a synthetic equivalent of either the parent propargylidyne $\left[\mathrm{W}(\equiv \mathrm{CC} \equiv \mathrm{CH})(\mathrm{CO})_{2}\left(\mathrm{Tp}^{*}\right)\right]$ or its conjugate base $\left[\mathrm{W}(\equiv \mathrm{CC} \equiv \mathrm{C})(\mathrm{CO})_{2}\left(\mathrm{Tp}^{*}\right)\right]^{-}$in reactions with a range of transition metal complexes, either by alkynyl $\mathrm{C}-\mathrm{H}$ activation of the former or halide metathesis with the latter (Scheme 1).

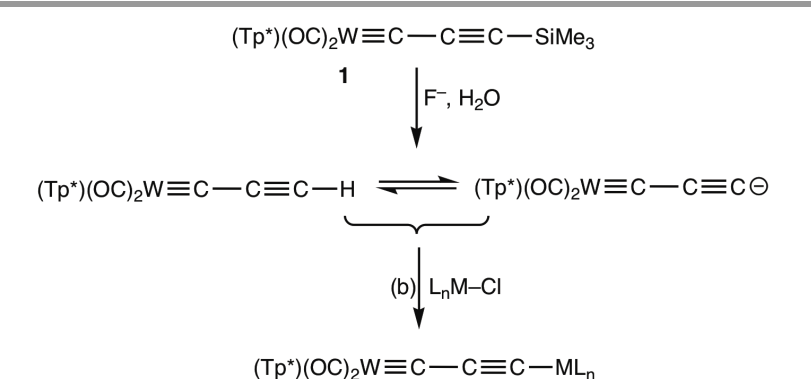

Scheme 1. Silylpropargylidyne desilylation as a route to $\mu$-tricarbido Complexes. ${ }^{2} \mathrm{~L}_{n} \mathrm{M}-\mathrm{Cl}$ $=\mathrm{HgCl}_{2}, \operatorname{IrCl}(\mathrm{CO})\left(\mathrm{PPh}_{3}\right)_{2}, \mathrm{RhCl}(\mathrm{CO})\left(\mathrm{PCy}_{3}\right)_{2}, \mathrm{RuHCl}(\mathrm{CO})\left(\mathrm{PPh}_{3}\right)_{3}, \mathrm{PtCl}_{2}\left(\mathrm{PPh}_{3}\right)_{2}$ inter alia.

Whilst this approach offers considerable generality for the formation of bimetallics $\left[\mathrm{W}\left(\equiv \mathrm{CC} \equiv C \mathrm{CML} \mathrm{L}_{n}\right)(\mathrm{CO})_{2}\left(\mathrm{Tp}^{*}\right)\right]$ with respect to ' $M L_{n}$ ' $(M=R h, I r, P d, P t, H g, A u)$, there are to date no

\footnotetext{
a. Research School of Chemistry, Australian National University, Acton, Canberra, A.C.T., Australia..

†Electronic Supplementary Information (ESI) available: Crystallographic information files CCDC C 1034120 - 1034121 and 1034163 relate to compounds discussed herein. Characterisational spectroscopic data for new compounds. See DOI: $10.1039 / x 0 x \times 00000 x$
}

examples where ' $\mathrm{M}$ ' is a main group element other than silicon. We have therefore considered the possibility of extending this approach to the synthesis of main-group element functionalised propargylidynes and describe herein our attempts to isolate selenolatopropargylidynes $\left[\mathrm{W}(\equiv \mathrm{CC} \equiv \mathrm{CSe} R)(\mathrm{CO})_{2}\left(\mathrm{Tp}^{*}\right)\right](\mathrm{R}=\mathrm{Ph}$, $\mathrm{Me})$. The choice of selenolato substituents builds on previous studies of other approaches to the construction of unsaturated organoselenium ligands that combine selenium with $s p$ hybridised carbon ${ }^{3}$ in which the $\mathrm{C}-\mathrm{Se}$ bond is a reactive site for subsequent cleavage reactions involving electron-rich metal centres. ${ }^{4}$

\section{Results and Discussion}

As noted above, propargylidyne ligands bearing heteroatoms other than silicon are presently unknown. An indication of their viability was however provided by the isolation of a bimetallic complex $[\mathrm{WRu}(\mu-$ $\left.\left.\mathrm{C}_{3} \mathrm{Se}\right)(\mathrm{CO})_{2}\left(\mathrm{PPh}_{3}\right)_{2}\left(\mathrm{Tp}^{*}\right)\left(\eta-\mathrm{C}_{5} \mathrm{H}_{5}\right)\right]$ which arose from the reaction of 1 with moist [ ${ }^{n} \mathrm{Bu}_{4} \mathrm{~N}$ ] F ('TBAF') ${ }^{\ddagger}$ in the presence of elemental (grey) selenium to afford the putative salt

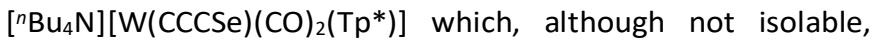
could be trapped by reaction with $\left[\mathrm{RuCl}\left(\mathrm{PPh}_{3}\right)_{2}\left(\eta-\mathrm{C}_{5} \mathrm{H}_{5}\right)\right.$ ] (Scheme 2). ${ }^{5}$

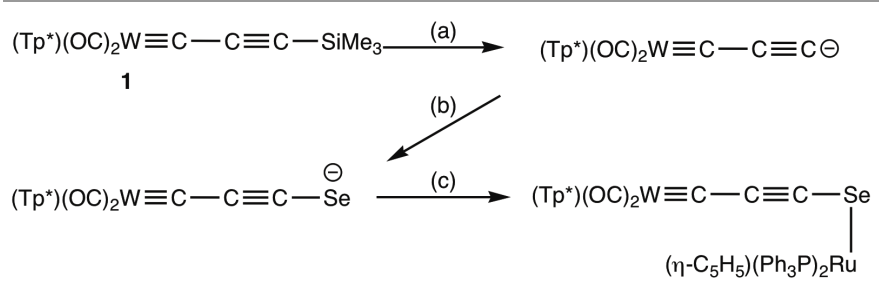

Scheme 2. Synthesis of a $\mu-C_{3}$ Se Bimetallic Complex. ${ }^{5}$ (a) $\left[{ }^{n} \mathrm{Bu}_{4} \mathrm{~N}\right] \mathrm{F}$; (b) $1 / \mathrm{nSe}_{n}$; (c) $\left[\mathrm{RuCl}\left(\mathrm{PPh}_{3}\right)_{2}\left(\eta-\mathrm{C}_{5} \mathrm{H}_{5}\right)\right] .^{5}$

We therefore commenced our studies by computationally interrogating the, as yet hypothetical, complex $\left[\mathrm{W}(\equiv \mathrm{CC} \equiv \mathrm{CSeMe})(\mathrm{CO})_{2}\left\{\mathrm{HB}(\mathrm{pz})_{3}\right\}\right]$ as a computationally simpler 
analogue of the target complex $\left[\mathrm{W}(\equiv \mathrm{CC} \equiv \mathrm{CSePh})(\mathrm{CO})_{2}\left(\mathrm{Tp}^{*}\right)\right](2)$. Figure 1 depicts optimised geometry for this complex, and includes the HOMO-1 orbital which of is interest in that it comprises WC and CC $\pi$-bonding contributions in addition to selenium lone pair character. The geometry at selenium $\left(97.8^{\circ}\right)$ is close to $90^{\circ}$ consistent with the increase in $p^{3}$ (i.e., no) hybridisation on descending group 16.

Table 1 provides geometric data for the WC3 spine alongside those calculated for the hypothetical propargylidynes $\left[\mathrm{W}(\equiv \mathrm{CC} \equiv \mathrm{CR})(\mathrm{CO})_{2}\left\{\mathrm{HB}(\mathrm{pz})_{3}\right\}\right] \quad\left(\mathrm{R}=\mathrm{H}, \mathrm{NO}_{2}, \mathrm{NMe}_{2}, \mathrm{SeMe}, \mathrm{SePh}\right)$ in addition to those calculated for the known silypropargylidyne complex $\left[\mathrm{W}\left(\equiv \mathrm{CC} \equiv \mathrm{CSiMe}_{3}\right)(\mathrm{CO})_{2}\left\{\mathrm{HB}(\mathrm{pz})_{3}\right\}\right]$ for which experimentally derived data are also available. ${ }^{2 \mathrm{~h}}$

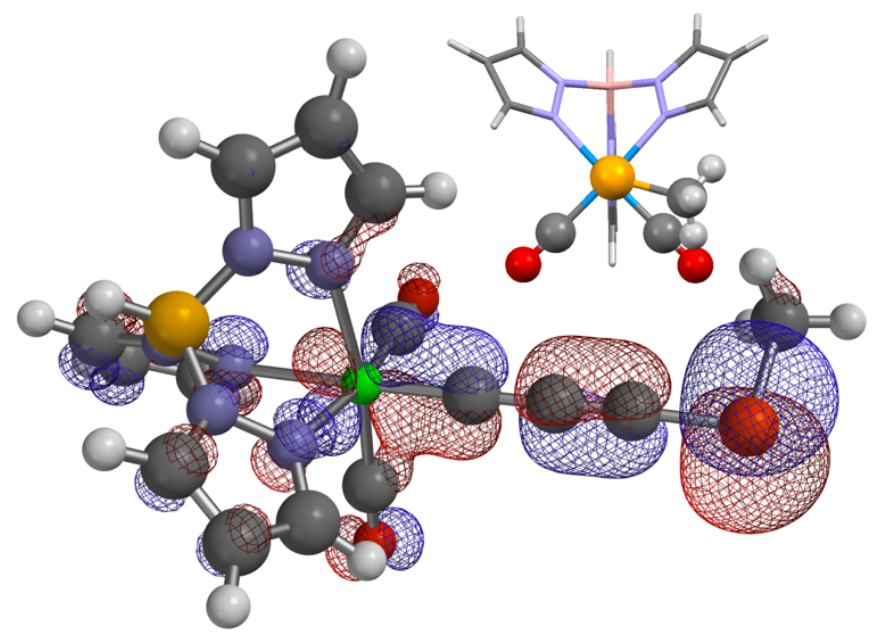

Figure 1. Optimised geometry for the complex $\left[\mathrm{W}(\equiv \mathrm{CC} \equiv \mathrm{CSeMe})(\mathrm{CO})_{2}(\mathrm{Tp})\right](\mathrm{DFT}$ : B3LYP-LANL2DZ level of theory) with HOMO-1 superimposed.

Table 1. Calculated geometric data (Å) for propargylidyne complexes $\left[\mathrm{W}(\equiv \mathrm{C} \alpha \mathrm{C} \beta \equiv \mathrm{C} \gamma \mathrm{R})(\mathrm{CO})_{2}(\mathrm{Tp})\right]^{a}{ }^{a}$

\begin{tabular}{|c|c|c|c|c|c|}
\hline $\mathbf{R}$ & $W \equiv C \alpha$ & $\mathrm{C} \alpha \mathrm{C} \beta$ & $C \beta \equiv C \gamma$ & WNt & $T R^{c}$ \\
\hline $\mathrm{H}$ & 1.848 & 1.373 & 1.227 & 2.306 & 1.039 \\
\hline $\mathrm{SiMe}_{3}$ & 1.852 & 1.368 & 1.238 & 2.304 & 1.037 \\
\hline $\mathrm{SiMe}_{3}{ }^{b}$ & 1.844 & 1.366 & 1.236 & 2.268 & 1.033 \\
\hline $\mathrm{NO}_{2}$ & 1.853 & 1.361 & 1.230 & 2.300 & 1.035 \\
\hline SeMe & 1.856 & 1.363 & 1.236 & 2.300 & 1.035 \\
\hline SePh & 1.858 & 1.363 & 1.237 & 2.306 & 1.038 \\
\hline $\mathrm{NMe}_{2}$ & 1.863 & 1.358 & 1.238 & 2.310 & 1.037 \\
\hline
\end{tabular}

The data in Table 1 suggest that geometric features along the $W_{C_{3}} R$ spine are not responsive to variations in the mesomeric nature of the substituent $\mathrm{R}$, with $\mathrm{R}=\mathrm{NMe}_{2}$ and $\mathrm{NO}_{2}$ representing extremes of $\boldsymbol{M}^{+}$and $\boldsymbol{M}^{-}$character. Similarly, there is little difference in the trans influence (TR) across the series of variously functionalised propargylidynes. Although a gradual increase in both the $\mathrm{W} \equiv \mathrm{C} \alpha$ and $\mathrm{WNt}$ bond lengths is discernible as the $\boldsymbol{M}^{+}$character of the substituent increases, it should be stressed that this is within the current level of crystallographic precision and would not be reliably determined experimentally.

In an attempt to access $\mathbf{2}$, a THF solution of $\mathbf{1}$ was treated with $\left[{ }^{n} \mathrm{Bu}_{4} \mathrm{~N}\right] \mathrm{F}\left({ }^{\prime} \mathrm{TBAF}\right)^{\ddagger}$ in the presence of diphenyldiselenide. This approach has proven successful in the synthesis of the selenolatocarbyne $\left[\mathrm{Mo}(\equiv \mathrm{CSePh})(\mathrm{CO})_{2}\left(\mathrm{Tp}^{*}\right)\right]$ via the reaction of the lithiocarbyne $\left[\mathrm{W}(\equiv \mathrm{CLi})(\mathrm{CO})_{2}\left(\mathrm{Tp}^{*}\right)\right]$ with $\mathrm{PhSeSePh} .^{7}$ Two compounds were isolated, however neither were the desired propargylidyne. The major (51\%) orange product corresponded to two regioisomers of the bis(phenylselenolato)allylidyne $E$ and $Z-\left[\mathrm{W}\{\equiv \mathrm{CC}(\mathrm{SePh})=\mathrm{CH}(\mathrm{SePh})\}(\mathrm{CO})_{2}\left(\mathrm{Tp}^{*}\right)\right] \quad(E / Z-3)$ whilst the minor was identified as the tris(phenylselenolato) derivative $\left[\mathrm{W}\left\{\equiv \mathrm{CC}(\mathrm{SePh})=\mathrm{C}(\mathrm{SePh})_{2}\right\}(\mathrm{CO})_{2}\left(\mathrm{Tp}^{*}\right)\right]$ (4). Although the $E$ and $Z$ isomers of $\mathbf{3}$ proved inseparable in bulk quantities, crystallographic grade crystals of the $E$-isomer were obtained and this isomer was structurally characterised (Figure 2). Spectroscopic data for each isomer could however be acquired from the 45:55 Z/E mixture. The vinylic $\mathrm{H} \gamma$ resonances at 7.82 and $7.15 \mathrm{ppm}$ are assigned to isomers $Z-3$ and $E-3$ respectively based on data from previous studies of vinylic selenoethers, which found the vinylic proton of the cis isomer generally resonates at a higher chemical shift relative to its corresponding trans isomer. ${ }^{8}$

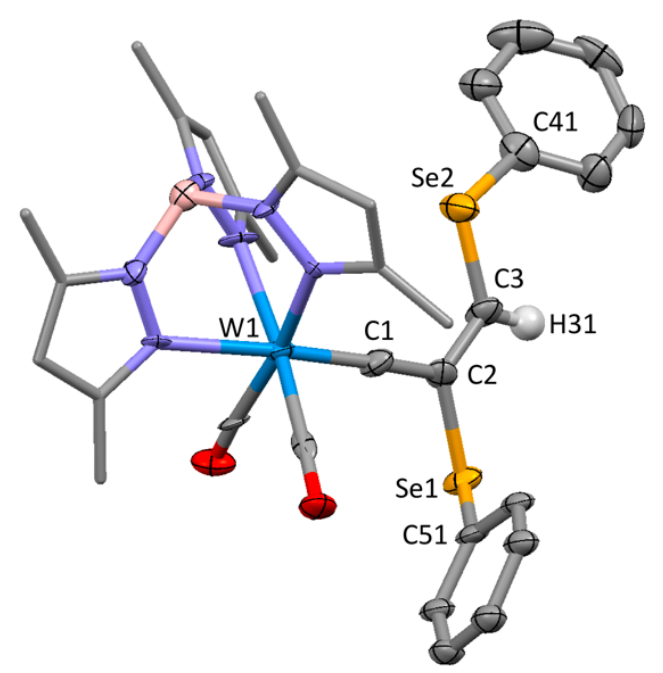

Figure 2. Molecular structure of $E-3$. ( $50 \%$ displacement ellipsoids, hydrogens omitted for clarity). Selected bond lengths ( $\AA$ ) and angles ( $\left.{ }^{\circ}\right)$ : W1-C1 1.832(15), C1-C2 1.44(2), C2-C3 1.34(2), W1-N11 2.291(12), Se1-C2 1.927(16), Se2-C3 1.881(15), W1-C1-C2 170.2 (13), C1-C2-C3 121.5(14), Se1-C2-C3 119.0(12), Se2-C3-C2 121.4(12).

In the ${ }^{13} \mathrm{C}\left\{{ }^{1} \mathrm{H}\right\}$ NMR spectrum, a range of informative heteronuclear couplings were displayed within the spectra. The $Z-3$ and $E-3$ carbyne $(W \equiv C)$ resonances at 267.7 and $269.3 \mathrm{ppm}$ appear as singlets straddled by ${ }^{183} \mathrm{~W}$ satellites $\left({ }^{183} \mathrm{~W}, I=1 / 2\right.$, $14.3 \%$ natural abundance), with ${ }^{1} J_{\mathrm{WC}}$ couplings of 193 and 195 $\mathrm{Hz}$, respectively, which are typical of more conventional tungsten-carbynes. Relative to the carbyne resonance for $\mathbf{1}$ (248.9 ppm) the carbyne resonances were shifted downfield, presumably in part reflecting the increased deshielding from the magnetic anisotropy associated with the directly attached vinyl $c f$. alkynyl substituent. The pair of carbonyl ligands in each isomer gives rise to a single resonance at $226.1 \mathrm{ppm}\left({ }^{1} J_{\mathrm{WC}}=164\right.$ $\mathrm{Hz})$ for Z-3 and $224.7 \mathrm{ppm}\left({ }^{1} J_{\mathrm{wc}}=165 \mathrm{~Hz}\right) \mathrm{ppm}$ for $E-3$. The resonances corresponding to $C \beta$ at 135.2 and $140.5 \mathrm{ppm}$ both displayed a set of ${ }^{183} \mathrm{~W}$ satellites with a ${ }^{2} J_{\mathrm{wC}}$ coupling of $50 \mathrm{~Hz}$, which is within the typical range for two-bond tungsten-carbon coupling. The $\mathrm{C} \gamma$ resonances at 133.6 and 143.7 ppm, whilst not displaying resolvable coupling to tungsten displayed ${ }^{1} J_{\text {CSe }}$ 
satellites (121 and $117 \mathrm{~Hz}$ ) well within the typical range found for one-bond carbon-selenium couplings ${ }^{9}\left({ }^{77} \mathrm{Se}, I=1 / 2,7.6 \%\right.$ natural abundance). The IR spectrum measured in THF displayed 2 different sets of stronger intensity $v_{\text {co }}$ absorptions at 1978 and $1891 \mathrm{~cm}^{-1}$ for E-3, with slightly less intense absorptions at $1973,1895 \mathrm{~cm}^{-1}$ for $Z-3$. The slight decrease in frequency for $Z-3$ is related to the position of the phenylselenide substituent trans to the tungsten-carbyne group, which would appear to slightly reduce the $\pi$-acidity of this carbyne relative to the $E$ isomer.

The IR spectrum of complex 4 comprised only a single set of $v_{\mathrm{CO}}$ absorptions at 1975 and $1891 \mathrm{~cm}^{-1}$ while the ${ }^{1} \mathrm{H}$ NMR spectrum displayed a similar resonance pattern to those of $E / Z-3$ but devoid of the resonance for $\mathrm{H} \gamma$, and with integration between $7.53-7.02 \mathrm{ppm}$ indicating three phenyl groups. The structure of complex 4 was confirmed by $X$-ray crystallographic analysis of crystals grown in DCM/hexane (Figure 3 ).

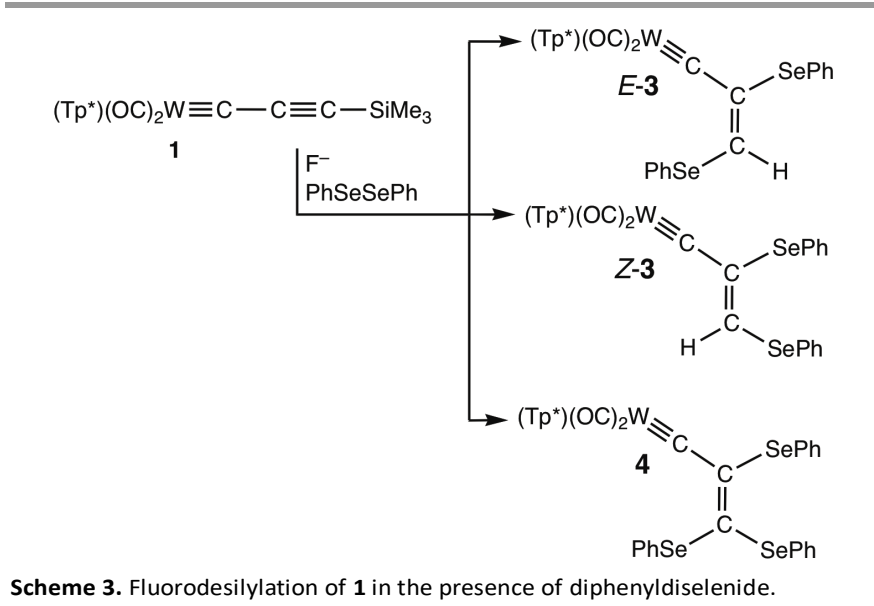

The crystal structures of E-3 and $\mathbf{4}$ display many similar structural features that are seen to parallel many group 6 alkylidyne complexes containing the " $\mathrm{Tp} *(\mathrm{CO})_{2} \mathrm{M}$ " ( $\mathrm{M}=\mathrm{Mo}$, W)" unit. ${ }^{10}$ Of primary interest, the short tungsten-carbyne bond lengths of $1.856(15)$ and 1.838(3) $\AA$ fall within the typical range for tungsten-carbon triple bonds. The nitrogen-tungsten bond trans to the carbyne ligand in both structures displays a slightly elongated bond $(2.279(12)$ and $2.286(2) \AA$ ) relative to those of the cis pyrazolyl ligands, reflecting the superlative trans influence characteristic of carbyne ligands. Comparison of these structures to the bimetallic vinyl alkylidyne complex $\left[\mathrm{Tp}^{*}(\mathrm{CO}){ }_{2} \mathrm{~W} \equiv \mathrm{CCMe}=\mathrm{CMeC} \equiv \mathrm{W}(\mathrm{CO})_{2} \mathrm{Tp}^{*}\right]^{11}$ reveals the $\mathrm{C} 1(s p)-$ $\mathrm{C} 2\left(s p^{2}\right)$ single bond $(1.41(2), 1.415(4) \AA)$ to be much longer relative to the $\mathrm{C} 2\left(s p^{2}\right)-\mathrm{C} 3\left(s p^{2}\right)$ double bond $(1.35(2)$ and $1.350(4) \AA$ ). The bond angles found between the vinyl carbons and their substituents are found to be within the range of 124.5 $-115.1^{\circ}$ as expected for conventional $s p^{2}$-hybridised carbon.

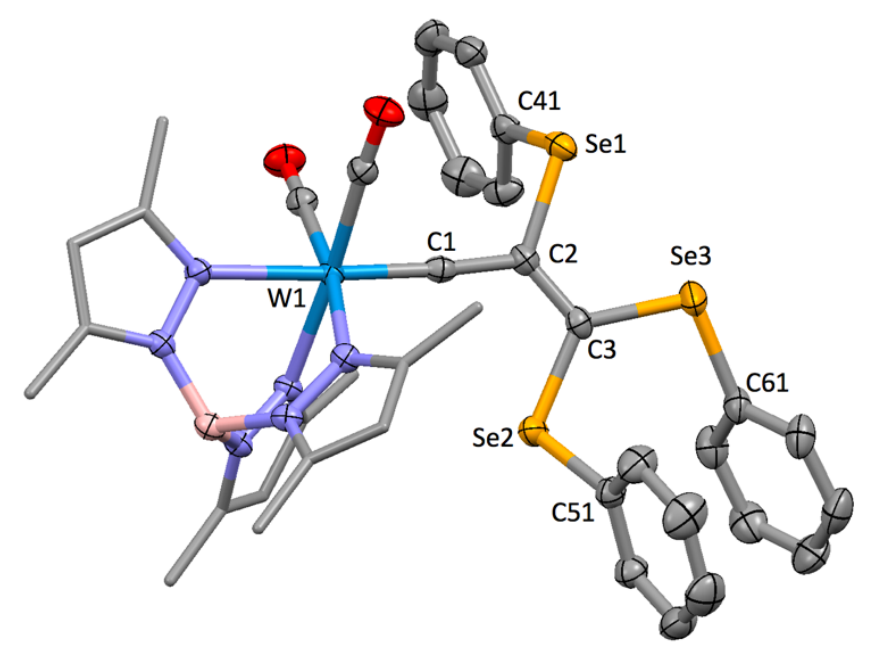

Figure 3. Molecular structure of $\mathbf{4}$ in a crystal ( $50 \%$ displacement ellipsoids, hydrogens omitted for clarity). Selected bond lengths ( $(\AA)$ and angles ( $\left.{ }^{\circ}\right)$ : W1-C1 1.838(3), C1-C2 1.415(4), C2-C3 1.350(4), W1-N11 2.286(2), Se1-C2 1.941(3), Se2-C3 1.908(3), Se3-C3 1.915(3), W1-C1-C2 174.3(2), C1-C2-C3 124.5(3), Se1-C2-C3 120.3(2), Se2-C3-C2 115.6(2), Se3-C3-C2 119.1(2).

The formation of $Z-\mathbf{3}, E-\mathbf{3}$ and $\mathbf{4}$ is presumed to proceed by a similar mechanism to that proposed by Zeni for the reaction of alkynyl nucleophiles with $\mathrm{Ph}_{2} \mathrm{Se}_{2} .{ }^{12}$ Firstly the formation of the desired phenylselenylpropargylidyne $\mathbf{5}$ also results in the generation of the strongly nucleophilic phenylselenolate anion (Scheme 4). The fluoride mediated protodesilylation of $\mathbf{1}$ is considered to generate an equilibrium mixture of $\left[\mathrm{W}(\equiv \mathrm{CC} \equiv \mathrm{CH})(\mathrm{CO})_{2}\left(\mathrm{Tp}^{*}\right)\right]$ and $\left[\mathrm{W}(\equiv \mathrm{CC} \equiv \mathrm{C})(\mathrm{CO})_{2}\left(\mathrm{Tp}^{*}\right)\right]^{-}$(Scheme 1$)$ such that nucleophilic attack by the $\mathrm{PhSe}^{-}$anion may occur at $\mathrm{C} \gamma$ of either the former or $\mathbf{5}$ to generate the anionic allenylidenes $\left[\mathrm{W}\{=\mathrm{C}=\mathrm{C}=\mathrm{C}(\mathrm{SePh}) \mathrm{R}\}(\mathrm{CO})_{2}\left(\mathrm{Tp}^{*}\right)\right]^{-}$which in turn react as nucleophiles towards further $\mathrm{Ph}_{2} \mathrm{Se}_{2}$ to provide the three final products. Whilst anionic allenylidene complexes have only recently been identified, ${ }^{6}$ neutral allenylidenes of the later transition metals are known to react with electrophiles at $C \beta$ to afford vinylcarbyne (allylidyne) complexes. ${ }^{13}$ The regioselectivity of electrophilic attack upon $\left[\mathrm{W}(=\mathrm{C}=\mathrm{C}=\mathrm{CHSePh})(\mathrm{CO})_{2}\left(\mathrm{Tp}^{*}\right)\right]^{-}$would be governed by approach of the electrophile coplanar with the $=\mathrm{CHSePh}$ unit and so a slight preference for the formation of $E-3$ might be expected. The comparatively low yield for the formation of $\mathbf{4}$ may be due to either (or both) slower attack by $\mathrm{PhSe}^{-}$at the electron-rich and sterically more congested 5 than $\left[\mathrm{W}(\equiv \mathrm{CC} \equiv \mathrm{CH})(\mathrm{CO})_{2}\left(\mathrm{Tp}^{*}\right)\right]$ or alternatively, more difficult approach of the $\mathrm{Ph}_{2} \mathrm{Se}_{2}$ electrophile due to steric occlusion by the $=\mathrm{C}(\mathrm{SePh})_{2}$ unit. This mechanistic conjecture considers only diamagnetic intermediates, however it should be noted that the addition of $\mathrm{Ph}_{2} \mathrm{Se}_{2}$ to activated alkynes has been shown to be photochemically (UV) induced, resulting in vinylic bis(selenoethers) via a radical pathway. ${ }^{14}$ Although the chemistry described herein was performed under laboratory fluorescent illumination, the possibility that radical addition of PhSeSePh occurs to transient $\mathbf{5}$ to generate $\mathbf{4}$ may not at this point be discounted. 


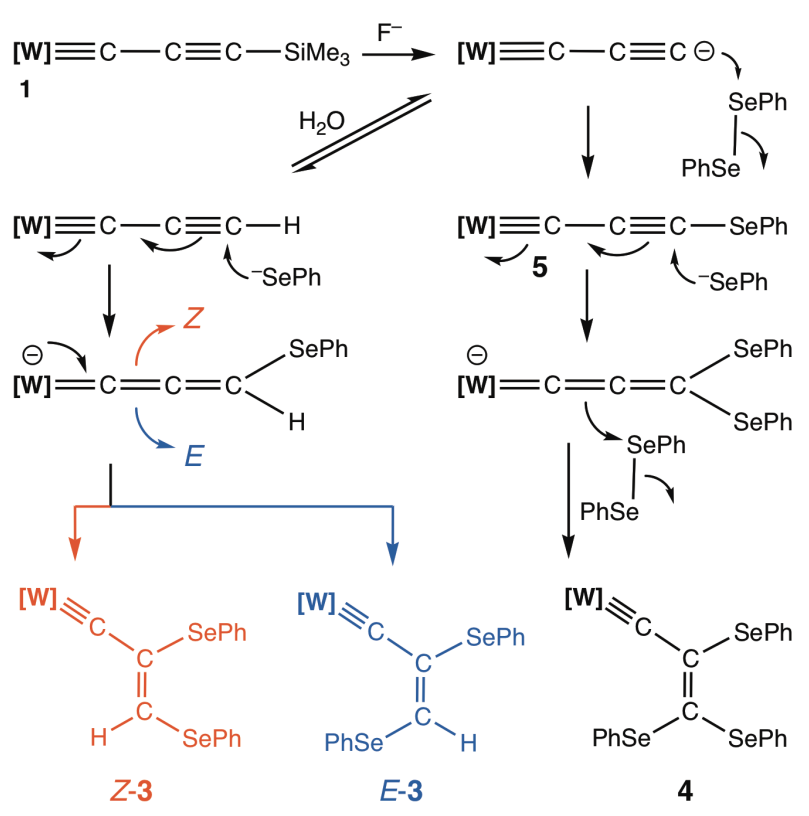

Scheme 4. Mechanistic conjecture to account for the conversion of $\mathbf{1}$ to $E / Z-\mathbf{3}$ and $\mathbf{4}$. [W] $=\mathrm{W}(\mathrm{CO})_{2}\left(\mathrm{Tp}^{*}\right)$.

Difficulties encountered in isolating useful amounts of complex 5 called for alternative preparative methods for introducing the phenylselenolate substituent. Specifically, the use of $\mathrm{Ph}_{2} \mathrm{Se}_{2}$ results in the formation of the strongly nucleophilic $\mathrm{PhSe}^{-}$anion, leading to multiple installations of this group. The moisture sensitive reagent $\mathrm{PhSeCl}$ (from chlorination of $\left.\mathrm{Ph}_{2} \mathrm{Se}_{2}\right)$, is a far stronger electrophile than $\mathrm{Ph}_{2} \mathrm{Se}_{2}$, however the conjugate nucleophile $\left(\mathrm{Cl}^{-}\right)$is comparatively unreactive. It was not considered the first choice as ' $\mathrm{PhSe}^{+}$electrophile due to its moisture sensitivity given that TBAF reagents are inevitably hydrated. ${ }^{15}$

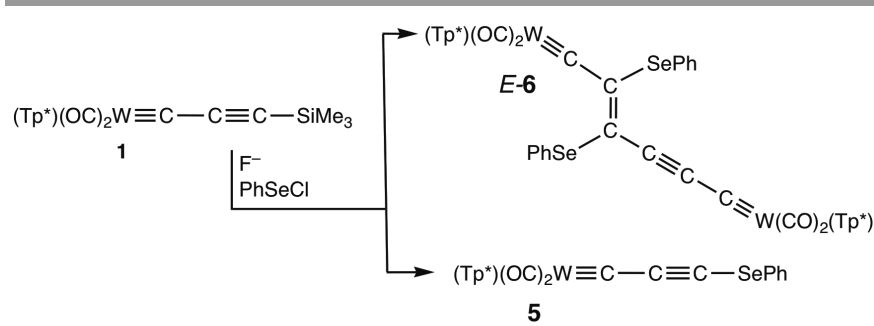

Scheme 5. Fluorodesilylation of $\mathbf{1}$ in the presence of phenylselenenyl chloride..

Treating a solution of complex 1 and $\mathrm{PhSeCl}$ with TBAF resulted in an instant colour change from red to dark red. The removal of solvent followed by chromatography (silica gel) revealed a multitude of different coloured compounds. The isolation of the first light red band gave the desired selenolatopropargylidyne complex 5 in $10 \%$ yield, which was characterised by NMR spectroscopy (Scheme 5). The ${ }^{13} \mathrm{C}\left\{{ }^{1} \mathrm{H}\right\}$ NMR spectrum revealed a carbyne resonance at $245.9 \mathrm{ppm}$, well within the typical range of similar unsaturated propargylidynes such as complex 1 . This appears upfield relative to the vinylcarbyne complexes $E / Z-3$ and $\mathbf{4}$ and can be attributed to an enhanced shielding caused by the magnetic anisotropy of the unsaturated alkynyl substituent. The $c \beta$ resonance appeared at $123.9 \mathrm{ppm}$ while the $\mathrm{C} \gamma$ resonance was observed to considerably higher frequency at $56.7 \mathrm{ppm}$, in a region typical of alkynyl selenoethers, e.g., $\mathrm{PhSeC} \equiv \mathrm{CC}_{6} \mathrm{H}_{4} \mathrm{Me}-4$ has alkynyl resonances at 103.2 and $68.2 \mathrm{ppm} .{ }^{16}$ The large difference in the chemical shift of the alkyne carbons is due to the directly attached substituents. A large inductive effect from the metal carbyne bond deshields the directly attached $C \beta$ causing it to resonate further downfield relative to $C \gamma$. The positively mesomeric $\left(\boldsymbol{M}^{+}\right)$SePh group is not as electron withdrawing $(\boldsymbol{I}-)$ as the carbyne leading to a significant upfield shift for $\mathrm{C} \gamma$. The $\mathrm{CO}$ ligands gave rise to a single ${ }^{13} \mathrm{C}$ resonance at $226.1 \mathrm{ppm}$ straddled by tungsten satellites $\left({ }^{1} J_{\mathrm{Wc}}=162 \mathrm{~Hz}\right)$, and two $v_{\mathrm{CO}}$ absorptions in the IR spectrum at 1971 and $1882 \mathrm{~cm}^{-1}$. In addition to the typical Tp* pattern for a molecule with $C_{s}$ local symmetry, the ${ }^{13} \mathrm{C}\left\{{ }^{1} \mathrm{H}\right\}$ NMR and ${ }^{1} \mathrm{H}$ NMR spectra both included resonances corresponding to the phenyl selenolate group between $129.7-127.3 \mathrm{ppm}$ and $7.52-7.29$ ppm, respectively. Even once isolated in pure form, the complex $\mathbf{5}$ was found to be highly unstable in both the solid state and in solution. Even under an inert (argon/nitrogen) atmosphere and at low temperature the complex decomposed within a few hours. In solution the complex $\mathbf{5}$ decomposes at a greater rate, compromising the acquisition of further characterisational data.

From the mixture of compounds formed from the reaction a second dark red complex was isolated and identified as $E$ $\left\{\mathrm{Tp} *(\mathrm{OC})_{2} \mathrm{~W} \equiv \mathrm{CC}(\mathrm{SePh})=\mathrm{C}(\mathrm{SePh}) \mathrm{C} \equiv \mathrm{CC} \equiv \mathrm{W}(\mathrm{CO}){ }_{2} \mathrm{Tp} *\right\}(E-6$, Scheme 5 ) in $11 \%$ yield. It appeared that Z-6 was also formed as a minor isomer, giving rise to a second manifold of less intense resonances in the ${ }^{1} \mathrm{H}$ NMR spectrum with the same pattern as E-6 (ca $30 \%$ by integration), but due to insufficient data it was not fully characterised. The dark red bimetallic complex is of an interesting chemical structure as it contains both alkenylcarbyne and polycarbyl moieties within the one structure (Figure 4).

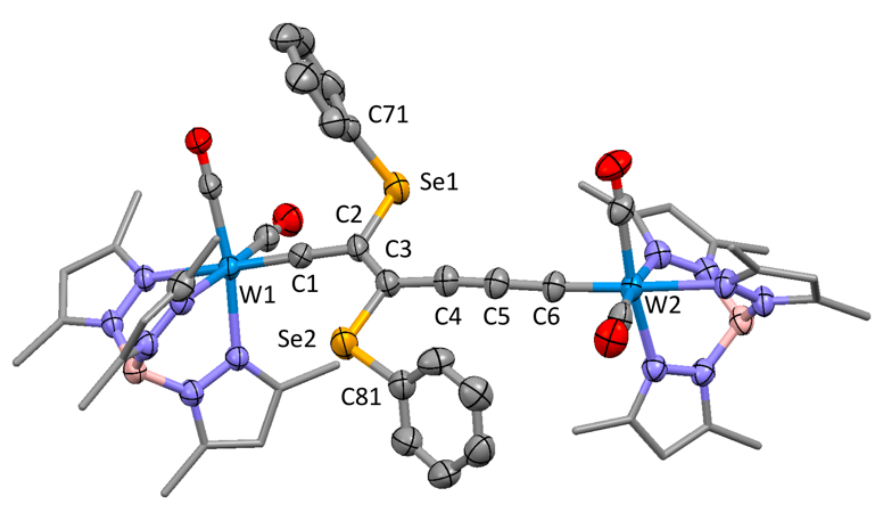

Figure 4. Molecular structure of 6 in a crystal of $6 . \mathrm{C}_{6} \mathrm{H}_{6}$. $(50 \%$ displacement ellipsoids, hydrogens and solvent omitted and pyrazolyl groups simplified for clarity) Selected bond lengths $(\AA)$ and angles $\left({ }^{\circ}\right)$ : W1-C1 1.842(5), W2-C6 1.849(5), C1-C2 1.403(6), C2- C3 1.367(7), C3-C4 1.397(7), C4-C5 1.199(7), C5-C6 1.367(7), W1-C1-C2 171.2(4), C1-C2-C3 123.7(5), Se1-C2-C3 119.4(3), Se2-C3-C2 114.4(3), C2-C3-C4 125.1(5), C3-C4-C5 175.1(6), C5-C6-W2 174.0(4).

The ${ }^{13} \mathrm{C}\left\{{ }^{1} \mathrm{H}\right\}$ and ${ }^{1} \mathrm{H}$ NMR spectra both display two sets of locally $C_{s}$-symmetric $\mathrm{Tp}^{*}$ resonances, characteristic of an unsymmetrical bimetallic compound. The two carbyne resonances in the ${ }^{13} \mathrm{C}\left\{{ }^{1} \mathrm{H}\right\}$ NMR spectra are found at markedly different chemical shifts with $268.7 \mathrm{ppm}$ corresponding to the 
alkenyl carbyne and the upfield resonance at $245.4 \mathrm{ppm}$ corresponding to the alkynyl carbyne. These assignments are based on the carbyne shifts observed for more conventional alkenyl and alkynyl carbynes, as discussed previously. Alkenyl resonances attributable to carbon nuclei along the bridging unsaturated carbon chain were observed at $136.3\left(C \beta^{\prime}\right)$ and $135.5 \mathrm{ppm}\left(\mathrm{C} \gamma^{\prime}\right)$, whilst the alkynyl resonances appeared further to higher field at $117.2(C \beta)$ and $69.0(C \gamma)$ ppm reflecting the effect of magnetic anisotropy of different regions of the unsaturated carbon chain. The assignment of these carbon resonances was aided greatly by ${ }^{13} \mathrm{C}-{ }^{1} \mathrm{H}$ HSQC and $\mathrm{HMBC}$ experiments confirming no direct or adjacent hydrogen correlation to these carbons. The IR spectra of complex E-6 displayed three $v_{\text {co }}$ adsorptions, two very strong adsorptions at 1972 and $1895 \mathrm{~cm}^{-1}$, with a medium adsorption at $1982 \mathrm{~cm}^{-1}$. The two tungsten termini are mutually somewhat distant and so the observation of only three absorptions most likely reflects overlap of the two lower energy $\left(v_{a s}\right)$ bands, rather than coupling of the remote oscillators. A very weak $v_{c} \equiv c$ adsorption was found at $2049 \mathrm{~cm}^{-1}$ characteristic of the $C \equiv C$ bond. The molecular structure of the $E-6$ isomer was crystallographically determined with data acquired from dark red crystals grown from benzene/hexane that confirmed the trans geometry around the double bond. The $\mathrm{W} \equiv \mathrm{C}$ bond distances were found to be approximately the same length (W1-C1 = 1.842(5) and W2-C6 = 1.849(5) $\AA$ ). The bond lengths between carbons along the unsaturated bridging chain appear somewhat contracted and suggest some degree of delocalisation of the $\pi$-orbitals. The C5-C6 bond $(1.367(7) \AA)$ is comparatively shorter than expected, and is found to be the same length as the $\mathrm{C} 2-\mathrm{C} 3$ alkene bond length (1.367(7) $\AA$ ). A general shortening of bond lengths C1-C2 (1.403(6) $\AA$ ) and C3-C4 (1.397(7) $\AA$ ) is apparent, falling within the range typical of propargylidyne complexes ${ }^{1}$ and alkenyl carbynes.6,10,11 The bond length of C3-C4 (1.199(7) $\AA)$ is well within the range for alkynes and diynes, being the shortest bond within the bridging chain, as expected. The angles W1-C1-C2 (171.2(4) $\left.{ }^{\circ}\right)$ and W2-C6-C5 $\left(174.0(4)^{\circ}\right)$ deviate only slightly from linearity, presumably due to packing effects within the crystal. The linearity continues down the alkyne chain all the way to the alkene group $\left(\mathrm{C} 3-\mathrm{C} 4-\mathrm{C} 5=175.1(6)^{\circ}\right)$.

The formation of complex $E-6$ is thought to proceed through a similar mechanism to that suggested for the formation of complexes $E / Z-3$ and $\mathbf{4}$ (Scheme 6). The initially formed $\mathbf{5}$ is prone to nucleophilic attack at the $C \gamma$ carbon by a second anionic tricarbido unit forming a bimetallic anionic allenylidene, which is trapped by further electrophilic attack at $\mathrm{C} \beta$ by $\mathrm{PhSeCl}$ to provide (predominantly) complex E-6.

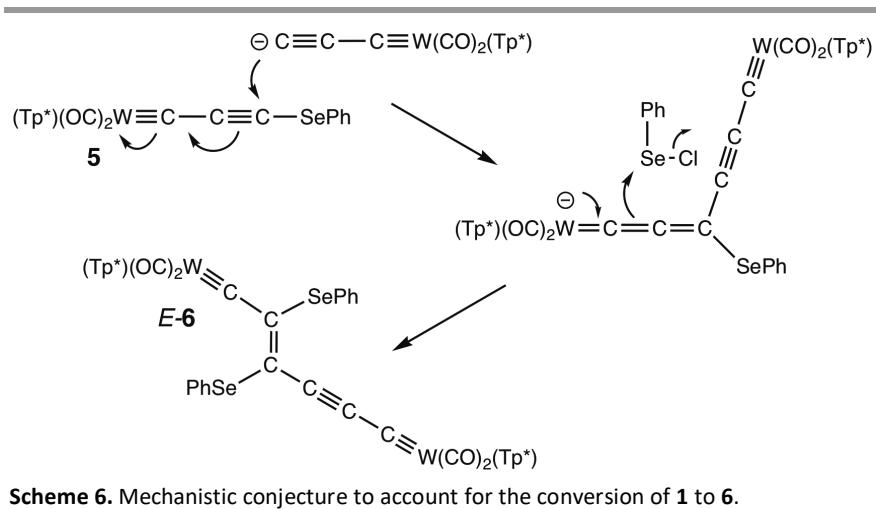

Scheme 6. Mechanistic conjecture to account for the conversion of $\mathbf{1}$ to $\mathbf{6}$.

An alternative approach to selenolatopropargylidynes was briefly explored with very limited success. As noted above, treating 1 with TBAF in the presence of elemental selenium generates a species formulated as $\left[{ }^{n} \mathrm{Bu}_{4} \mathrm{~N}\right]\left[\mathrm{W}(\mathrm{CCCSe})(\mathrm{CO})_{2}\left(\mathrm{Tp}^{*}\right)\right]$ and whilst this has so far eluded isolation, it may be trapped by reaction with $\left[\mathrm{RuCl}\left(\mathrm{PPh}_{3}\right)_{2}(\eta-\right.$ $\left.\mathrm{C}_{5} \mathrm{H}_{5}\right)$ ]. We therefore reasoned that trapping the same species with iodomethane should afford the complex $\left[\mathrm{W}(\equiv \mathrm{CC} \equiv \mathrm{CSeMe})(\mathrm{CO})_{2}\left(\mathrm{Tp}^{*}\right)\right](\mathbf{7})$ akin to 5 . In practice this lead to a plethora of compounds and conditions were not identified that would allow one to predominate. Nevertheless, extensive chromatographic purification did allow the isolation of traces of a compound $\mathbf{8}$, the formation of which does indeed point to the intermediacy of $\mathbf{7}$. The formulation of $\mathbf{8}$ rests somewhat disappointingly on limited spectroscopic data $\left({ }^{1} \mathrm{H} N M R, I R\right)$ due to the extremely low yield in addition to a single crystal structure determination (Figure 5), which whilst of limited precision, nevertheless confirms the gross connectivity.

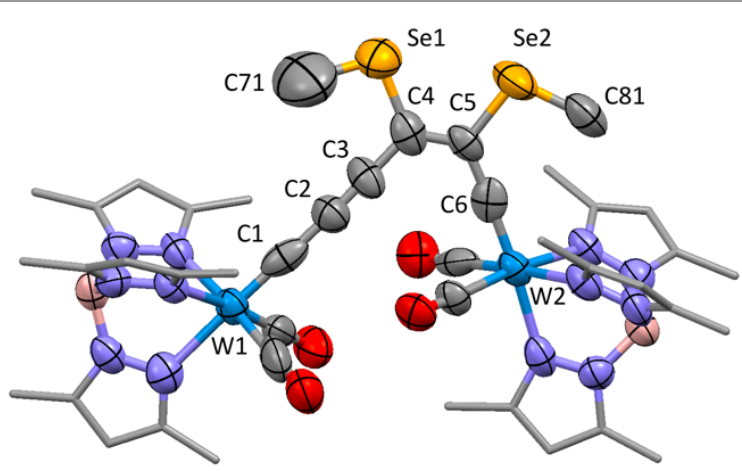

Figure 5. Molecular structure of 8 in a crystal (60\% displacement ellipsoids, hydrogens omitted for clarity). Precision of the structural model compromised by poor quality data.

Complex 8 (Scheme 7) is a further example of a binuclear bis(carbyne) complex with a $\mathrm{C}_{6}$ spine to which two selenolate groups are appended, akin to Z-6. Its formation may be rationalised by the incomplete conversion of $\left[{ }^{n} \mathrm{Bu}_{4} \mathrm{~N}\right]\left[\mathrm{W}(\mathrm{CCC})(\mathrm{CO})_{2}\left(\mathrm{Tp}^{*}\right)\right]$ to $\left[{ }^{n} \mathrm{Bu}_{4} \mathrm{~N}\right]\left[\mathrm{W}(\mathrm{CCCSe})(\mathrm{CO})_{2}\left(\mathrm{Tp}^{*}\right)\right]$, a problem also encountered in the synthesis of $[\mathrm{WRu}(\mu-$ $\left.\left.\mathrm{C}_{3} \mathrm{Se}\right)(\mathrm{CO})_{2}\left(\mathrm{PPh}_{3}\right)_{2}\left(\mathrm{Tp}^{*}\right)\left(\eta-\mathrm{C}_{5} \mathrm{H}_{5}\right)\right]$, whereby small amounts of the corresponding tricarbido-bridged species [WRu( $\mu$ $\left.\left.\mathrm{C}_{3}\right)(\mathrm{CO})_{2}\left(\mathrm{PPh}_{3}\right)_{2}\left(\mathrm{Tp}^{*}\right)\left(\eta-\mathrm{C}_{5} \mathrm{H}_{5}\right)\right]$ were also obtained. ${ }^{5}$ Methylation of $\left[{ }^{n} \mathrm{Bu}_{4} \mathrm{~N}\right]\left[\mathrm{W}(\mathrm{CCCSe})(\mathrm{CO})_{2}\left(\mathrm{Tp}^{*}\right)\right]$ thus appears to form the desired propargylidyne $\mathbf{7}$, however, this is then attacked by the 
$\left[\mathrm{W}(\mathrm{CCC})(\mathrm{CO})_{2}\left(\mathrm{Tp}^{*}\right)\right]^{-}$anion which in turn reacts with selenium and iodomethane to provide the final product. Whilst this remains conjecture, it provides a further indication that the $\gamma$ carbon of propargylidynes are especially prone to nucleophilic attack.

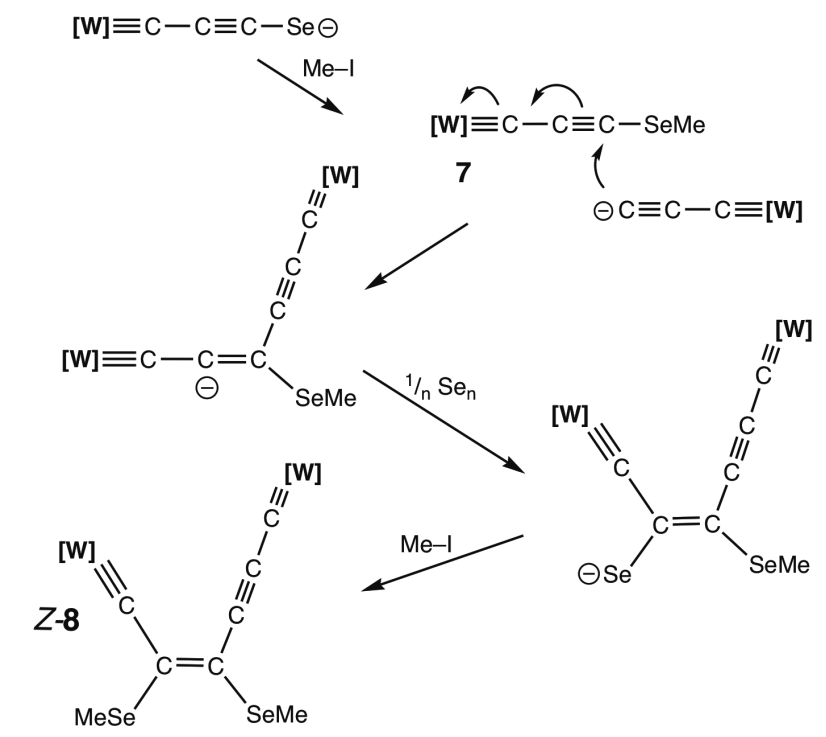

Scheme 7. Mechanistic conjecture to account for the formation of a 2,3bis(methylselenolato)dimetallaocten-triyne 8. $[\mathrm{W}]=\mathrm{W}(\mathrm{CO})_{2}\left(\mathrm{Tp}^{*}\right)$.

\section{Experimental}

General Considerations. Unless otherwise stated, all experimental work was carried out at room temperature under a dry and oxygen-free nitrogen atmosphere using standard Schlenk, vacuum line and inert atmosphere (argon) drybox techniques. Solvents tetrahydrofuran, toluene, pentane and hexane were dried and distilled under a nitrogen atmosphere from benzophenone and sodium. Dichloromethane was dried and distilled under a nitrogen atmosphere from calcium hydride. The silica gel used for chromatography was dried in an oven at $100^{\circ} \mathrm{C}$, evacuated and saturated with nitrogen prior to use. Once isolated, compounds were generally stored as solids under a nitrogen or argon atmosphere at $-20^{\circ} \mathrm{C}$. NMR spectra were obtained at $25^{\circ} \mathrm{C}$ on Bruker AVANCE $400\left({ }^{1} \mathrm{H}\right.$ at 399.9 $\mathrm{MHz})$, Bruker AVANCE $600\left({ }^{1} \mathrm{H} N M R\right.$ at $600.0 \mathrm{MHz},{ }^{13} \mathrm{C} N \mathrm{NR}$ at $150.9 \mathrm{MHz})$ or Bruker AVANCE $800\left({ }^{1} \mathrm{H}\right.$ NMR at $800.1 \mathrm{MHz},{ }^{13} \mathrm{C}$ NMR at $201.0 \mathrm{MHz}$ ) spectrometers. Chemical shifts $(\delta)$ are reported in ppm and referenced to the solvent peaks. The multiplicities of NMR resonances are denoted by the abbreviations $s$ (singlet), $d$ (doublet), $t$ (triplet), $m$ (multiplet) and combinations thereof for more highly coupled systems. Infrared spectra were obtained using a Perkin-Elmer Spectrum One FT-IR spectrometer. Electro-spray ionisation mass spectrometry (ESI-MS) was performed by the ANU Research School of Chemistry mass spectrometry service with acetonitrile as the matrix. A recurrent feature was the appearance under high-resolution conditions of a peak corresponding to $[\mathrm{M}-\mathrm{H}]^{+}$ which perhaps reflects the hydridic nature of the $\mathrm{B}-\mathrm{H}^{\delta-}$ bond of the $\mathrm{Tp}^{*}$ ligand, i.e., $\left[\mathrm{M}+\mathrm{H}-\mathrm{H}_{2}\right]^{+}$. Data for $\mathrm{X}$-ray crystallography were collected on Oxford Diffraction Xcalibur or SuperNova diffractometers. The compound $\left[\mathrm{W}\left(\equiv \mathrm{CC} \equiv \mathrm{CSiMe}_{3}\right)(\mathrm{CO})_{2}\left(\mathrm{Tp}^{*}\right)\right]$ (1), ${ }^{1 \mathrm{~b}}$ was prepared according to a published procedure. All other reagents were obtained from commercial sources. ${ }^{\ddagger}$

Synthesis of $E / Z-\left[W\{\equiv C C(S e P h)=C H S e P h\}(C O)_{2}\left(T^{*}\right)\right](E / Z-$ 3). A mixture of $\left[\mathrm{W}(\equiv \mathrm{CC} \equiv \mathrm{CSiMe})(\mathrm{CO})_{2}\left(\mathrm{Tp}^{*}\right)\right](\mathbf{1}: 100 \mathrm{mg}, 0.16$ $\mathrm{mmol}$ ) and diphenyl diselenide (50 $\mathrm{mg}, 0.16 \mathrm{mmol}$ ) in THF (30 $\mathrm{mL})$ was treated with a solution of $\left[{ }^{n} \mathrm{Bu}_{4} \mathrm{~N}\right] \mathrm{F}$ in $\mathrm{THF}(0.16 \mathrm{~mL}, 1.0$ $\mathrm{M}, 0.16 \mathrm{mmol}$ ) and left to stir at room temperature for $2 \mathrm{~h}$ providing a dark orange solution. The solvent was removed under high vacuum to leave a dark orange solid. The resulting solid was extracted into $\mathrm{CH}_{2} \mathrm{Cl}_{2}$ and chromatographed on a silica gel column, eluting with hexane/ $\mathrm{CH}_{2} \mathrm{Cl}_{2}$ (4:1). The major orange band was collected and the solvent removed under high vacuum to provide an orange solid, $[\mathrm{W}\{\equiv \mathrm{CC}(\mathrm{SePh})=\mathrm{CHSePh}\}$ $(\mathrm{CO})_{2}\left(\mathrm{Tp}^{*}\right)$ ], as a mixture of $E-3$ and $Z-3$ isomers. Yield: $73 \mathrm{mg}$ (51\%). MS (ESI - high resolution, +ve ion): $m / z=887.0520$. Calcd. for $\mathrm{C}_{32} \mathrm{H}_{32}{ }^{11} \mathrm{BN}_{6} \mathrm{O}_{2}{ }^{80} \mathrm{Se}_{2}{ }^{184} \mathrm{~W}$ : 887.0520. E-3: IR (THF): $v_{\mathrm{CO}}$ $=1978 \mathrm{~s}, 1891 \mathrm{vs} \mathrm{cm}^{-1} .{ }^{1} \mathrm{H} \mathrm{NMR}\left(\mathrm{CDCl}_{3}, 25^{\circ} \mathrm{C}, 800 \mathrm{MHz}\right): \delta_{\mathrm{H}}=7.63$ $-7.20\left(\mathrm{~m}, 10 \mathrm{H}, \mathrm{C}_{6} \mathrm{H}_{5}\right), 7.15(\mathrm{~s}, 1 \mathrm{H}, \mathrm{H} \gamma), 5.88(2 \mathrm{H}), 5.75(1 \mathrm{H})(\mathrm{s}$ $\times 2,3 \mathrm{H}, \mathrm{pz}-\mathrm{H}), 2.55(6 \mathrm{H}), 2.40(6 \mathrm{H}), 2.37(3 \mathrm{H}), 2.34(3 \mathrm{H})(\mathrm{s} \times$ 4, $\left.18 \mathrm{H}, \mathrm{pzCH}_{3}-3,5\right) \cdot{ }^{13} \mathrm{C}\left\{{ }^{1} \mathrm{H}\right\} \mathrm{NMR}\left(\mathrm{CDCl}_{3}, 25^{\circ} \mathrm{C}, 201 \mathrm{MHz}\right): \delta_{\mathrm{C}}=$ $269.3\left(s+d,{ }^{1} J_{w c}=195, W \equiv C \alpha\right), 226.1\left(s+d,{ }^{1} J_{w c}=163.8, C O\right)$, $152.4\left[\mathrm{C}^{5}(\mathrm{pz})\right], 152.3\left[\mathrm{C}^{5}(\mathrm{pz})\right], 145.1\left[\mathrm{C}^{3}(\mathrm{pz})\right], 144.3\left[\mathrm{C}^{3}(\mathrm{pz})\right]$, $135.2\left(s+d,{ }^{2} J_{W c}=50, C \beta\right), 133.6\left(s+d,{ }^{1} J_{C s e}=121, C \gamma, \mathrm{HSQ}\right.$ correlation with $\left.\delta_{H}=7.15\right), 132.8\left[\mathrm{C}^{2,6}\left(\mathrm{C}_{6} \mathrm{H}_{5}\right)\right], 132.5\left[\mathrm{C}^{2,6}\left(\mathrm{C}_{6} \mathrm{H}_{5}\right)\right]$, $131.6\left[\mathrm{C}^{1}\left(\mathrm{C}_{6} \mathrm{H}_{5}\right)\right], 131.0\left[\mathrm{C}^{1}\left(\mathrm{C}_{6} \mathrm{H}_{5}\right)\right], 129.3\left[\mathrm{C}^{3,5}\left(\mathrm{C}_{6} \mathrm{H}_{5}\right)\right], 129.1$ $\left[\mathrm{C}^{3,5}\left(\mathrm{C}_{6} \mathrm{H}_{5}\right)\right], 127.3\left[\mathrm{C}^{4}\left(\mathrm{C}_{6} \mathrm{H}_{5}\right)\right], 126.9\left[\mathrm{C}^{4}\left(\mathrm{C}_{6} \mathrm{H}_{5}\right)\right], 106.7\left[\mathrm{C}^{4}(\mathrm{pz})\right]$, $106.4\left[\mathrm{C}^{4}(\mathrm{pz})\right], 16.6,15.3,12.9,12.7\left(\mathrm{pzCH}_{3}\right)$. Crystals suitable for diffractometry were obtained by slow diffusion of hexane into a solution of the $E / Z-3$ isomeric mixture in chloroform. The structural model confirmed the connectivity but was of low precision due to positional disorder. Crystal data: $\mathrm{C}_{32} \mathrm{H}_{33} \mathrm{BN}_{6} \mathrm{O}_{2} \mathrm{Se}_{2} \mathrm{~W}, M_{\mathrm{r}}=886.22, T=150(2) \mathrm{K}$, orthorhombic, space group $P$ bca, $a=10.0753(2), b=20.7893(6), c=31.3879(8)$

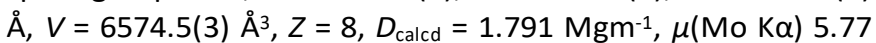
$\mathrm{mm}^{-1}$, red plate, $0.21 \times 0.18 \times 0.03 \mathrm{~mm}, 92,531$ measured reflections with $2 \theta \max =52.8^{\circ}, 6,714$ independent reflections, 6,714 absorption-corrected data used in $F^{2}$ refinement, 403 parameters, 153 restraints, $R_{1}=0.094, w R_{2}=0.215$ for 5,525 reflection with $I>2 \sigma(l)$ CCDC 1034120. Z-3: $v_{\mathrm{CO}}=1973 \mathrm{~s}, 1895$ vs $\mathrm{cm}^{-1} .{ }^{1} \mathrm{H} \mathrm{NMR}\left(\mathrm{CDCl}_{3}, 25^{\circ} \mathrm{C}, 800 \mathrm{MHz}\right): \delta_{\mathrm{H}}=7.82(\mathrm{~s}, 1 \mathrm{H}, \mathrm{H} \beta)$ $7.63-7.20\left(\mathrm{~m}, 10 \mathrm{H}, \mathrm{C}_{6} \mathrm{H}_{5}\right) 5.84(2 \mathrm{H}), 5.74(1 \mathrm{H})(\mathrm{s} \times 2,3 \mathrm{H}, \mathrm{pz}-$ $\mathrm{H}), 2.44(6 \mathrm{H}), 2.36(6 \mathrm{H}), 2.36(3 \mathrm{H}), 2.32(3 \mathrm{H})\left(\mathrm{s} \times 4,18 \mathrm{H}, \mathrm{pzCH}_{3}-\right.$ $3,5) .{ }^{13} \mathrm{C}\left\{{ }^{1} \mathrm{H}\right\} \mathrm{NMR}\left(\mathrm{CDCl}_{3}, 25^{\circ} \mathrm{C}, 150 \mathrm{MHz}\right): \delta_{\mathrm{C}}=267.7\left(\mathrm{~s}+\mathrm{d},{ }^{1} \mathrm{JWC}_{\mathrm{WC}}\right.$ $=193, \mathrm{~W} \equiv \mathrm{C}), 224.7\left(\mathrm{~s}+\mathrm{d},{ }^{1} J_{\mathrm{WC}}=165, \mathrm{CO}\right), 152.3\left[\mathrm{C}^{5}(\mathrm{pz})\right], 152.2$ $\left[C^{5}(p z)\right], 145.1\left[C^{3}(p z)\right], 144.4\left[C^{3}(p z)\right], 143.7\left(s+d,{ }^{1} J_{c S e}=117\right.$, $\mathrm{C} \gamma), 140.5\left(\mathrm{~s}+\mathrm{d},{ }^{2} J_{\mathrm{WC}}=50 \mathrm{~Hz}, \mathrm{C} \beta, \mathrm{HSQ}\right.$ correlation with $\delta_{\mathrm{H}}=$ 7.82), $133.0\left[\mathrm{C}^{2,6}\left(\mathrm{C}_{6} \mathrm{H}_{5}\right)\right], 131.7\left[\mathrm{C}^{2,6}\left(\mathrm{C}_{6} \mathrm{H}_{5}\right)\right], 131.0\left[\mathrm{C}^{1}\left(\mathrm{C}_{6} \mathrm{H}_{5}\right)\right]$, $130.4\left[\mathrm{C}^{1}\left(\mathrm{C}_{6} \mathrm{H}_{5}\right)\right], 129.6\left[\mathrm{C}^{3,5}\left(\mathrm{C}_{6} \mathrm{H}_{5}\right)\right], 129.2\left[\mathrm{C}^{3,5}\left(\mathrm{C}_{6} \mathrm{H}_{5}\right)\right], 128.0$ $\left[\mathrm{C}^{4}\left(\mathrm{C}_{6} \mathrm{H}_{5}\right)\right], 127.6\left[\mathrm{C}^{4}\left(\mathrm{C}_{6} \mathrm{H}_{5}\right)\right], 106.7\left[\mathrm{C}^{4}(\mathrm{pz})\right], 106.5\left[\mathrm{C}^{4}(\mathrm{pz})\right], 16.9$, 15.4, 12.8, $12.7\left(\mathrm{pzCH}_{3}\right)$.

Synthesis of $\left[\mathrm{W}\left(\equiv \mathrm{CC}(\mathrm{SePh})=\mathrm{C}(\mathrm{SePh})_{2}\right\}(\mathrm{CO})_{2}\left(\mathrm{Tp}^{*}\right)\right](4)$ - The same procedure for the synthesis of $E / Z-3$ was used, as above. The initially obtained solid was extracted into $\mathrm{CH}_{2} \mathrm{Cl}_{2}$ and chromatographed on a silica gel column, eluting with 
hexane $/ \mathrm{CH}_{2} \mathrm{Cl}_{2}$ (4:1). The second, minor yellow/green band was collected and the solvent was removed under high vacuum to obtain the yellow solid 4. Yield: $17 \mathrm{mg}(10 \%)$. IR (THF): $\delta_{H}=1975$ $\mathrm{s}, 1891 \mathrm{vs} \mathrm{cm}^{-1} .{ }^{1} \mathrm{H} \mathrm{NMR}\left(\mathrm{CDCl}_{3}, 25^{\circ} \mathrm{C}, 400 \mathrm{MHz}\right): 7.55-7.02(\mathrm{~m}$, $15 \mathrm{H}, \mathrm{Ph}), 5.82(2 \mathrm{H}), 5.70(1 \mathrm{H})(\mathrm{s} \times 2,3 \mathrm{H}, \mathrm{pzH}), 2.54(6 \mathrm{H}), 2.36$ $(6 \mathrm{H}), 2.30(3 \mathrm{H}), 2.30(3 \mathrm{H})\left(\mathrm{s} \times 4,18 \mathrm{H}, \mathrm{pzCH}_{3}-3,5\right) . \mathrm{MS}(\mathrm{ESI}-$ high resolution, +ve ion): $m / z=1042.9998$. Calcd. for $\mathrm{C}_{38} \mathrm{H}_{36}{ }^{11} \mathrm{BN}_{6} \mathrm{O}_{2}{ }^{80} \mathrm{Se}_{3}{ }^{184} \mathrm{~W}: 1042.9998[\mathrm{M}-\mathrm{H}]^{+}$. Crystals suitable for diffractometry were grown by slow diffusion of hexane into a solution of the complex in $\mathrm{CH}_{2} \mathrm{Cl}_{2}$. Crystal Data: $\mathrm{C}_{38} \mathrm{H}_{37} \mathrm{BN}_{6} \mathrm{O}_{2} \mathrm{Se}_{3} \mathrm{~W}, M_{\mathrm{r}}=1041.29, T=150 \mathrm{~K}(2)$, monoclinic, space group $P 2_{1} / c, a=10.1266(1), b=24.3602(2), c=15.7309$ (1) $\AA$, $\beta$ $=91.6627(6)^{\circ}, \mathrm{V}=3878.96(6) \AA^{3}, Z=4, D_{\text {calcd }}=1.783 \mathrm{Mgm}^{-3}$, $\mu\left(\right.$ Cu Ka) $9.07 \mathrm{~mm}^{-1}$, red block, $0.29 \times 0.21 \times 0.18 \mathrm{~mm}, 24,606$ measured reflections with $2 \theta_{\max }=144.6^{\circ}, 7,574$ independent reflections, 7549 adsorption-corrected data used in $F^{2}$ refinement, 460 parameters, no restraints, $R_{1}=0.027, w R_{2}=$ 0.060 for 7,483 reflections with $I>2 \sigma(I)$, CCDC 1034122 . Insufficient material was obtained for the acquisition of elemental microanalytical data and useful ${ }^{13} \mathrm{C}\left\{{ }^{1} \mathrm{H}\right\}$ NMR data.

Synthesis of $\left[\mathrm{W}(\equiv \mathrm{CC} \equiv \mathrm{CSePh})(\mathrm{CO})_{2}\left(\mathrm{Tp}^{*}\right)\right](5)$ - A mixture of $\left[\mathrm{W}\left(\equiv \mathrm{CC} \equiv \mathrm{CSiMe}_{3}\right)(\mathrm{CO})_{2}\left(\mathrm{Tp}^{*}\right)\right] \quad(\mathbf{1}: 100 \mathrm{mg}, 0.16 \mathrm{mmol})$ and phenylselenyl chloride (30 $\mathrm{mg}, 0.16 \mathrm{mmol}$ ) in THF (30 mL) was treated with a solution of $\left[{ }^{n} \mathrm{Bu}_{4} \mathrm{~N}\right] \mathrm{F}$ in THF $(0.16 \mathrm{~mL}, 1.0 \mathrm{M}, 0.16$ $\mathrm{mmol})^{\ddagger}$ and left to stir for 20 minutes at r.t. to provide a dark red solution. The solvent was removed under high vacuum to leave a dark red solid. The resulting solid was extracted into $\mathrm{CH}_{2} \mathrm{Cl}_{2}$ and chromatographed on a silica gel column, eluting with hexane/ $\mathrm{CH}_{2} \mathrm{Cl}_{2}$ (7:3). The pink band was collected and solvent freed of volatiles under high vacuum to obtain $\mathbf{5}$ as a dark pink solid. The compound must be stored in a freezer but still deteriorates over 1-2 days. Yield: $11 \mathrm{mg}(10 \%)$. IR (THF): $v_{\mathrm{CO}}=$ $1971 \mathrm{~s}, 1882$ vs cm${ }^{-1} .{ }^{1} \mathrm{H} \mathrm{NMR}\left(\mathrm{CDCl}_{3}, 25^{\circ} \mathrm{C}, 600 \mathrm{MHz}\right): \delta_{\mathrm{H}}=7.52$ $-7.29\left(\mathrm{~m}, 5 \mathrm{H}, \mathrm{C}_{6} \mathrm{H}_{5}\right), 5.91(2 \mathrm{H}), 5.75(1 \mathrm{H})(\mathrm{s} \times 2,3 \mathrm{H}, \mathrm{pz}-\mathrm{H}), 2.58$ $(6 \mathrm{H}), 2.37(9 \mathrm{H}), 2.32(3 \mathrm{H}),\left(\mathrm{s} \times 3,18 \mathrm{H}, \mathrm{pzCH}_{3}-3,5\right) .{ }^{13} \mathrm{C}\left\{{ }^{1} \mathrm{H}\right\} \mathrm{NMR}$ $\left(\mathrm{CDCl}_{3}, 25^{\circ} \mathrm{C}, 150 \mathrm{MHz}\right): \delta_{\mathrm{C}}=245.9(\mathrm{~W} \equiv \mathrm{C}), 226.3\left(\mathrm{~s}+\mathrm{d},{ }^{1} J_{\mathrm{wC}}=\right.$ $162 \mathrm{~Hz}, \mathrm{CO}), 152.5\left[\mathrm{C}^{5}(\mathrm{pz})\right], 152.4\left[\mathrm{C}^{5}(\mathrm{pz})\right], 145.4\left[\mathrm{C}^{3}(\mathrm{pz})\right], 144.6$ $\left[\mathrm{C}^{3}(\mathrm{pz})\right], 129.7\left[\mathrm{C}^{2,6}\left(\mathrm{C}_{6} \mathrm{H}_{5}\right)\right], 129.3\left[\mathrm{C}^{1}\left(\mathrm{C}_{6} \mathrm{H}_{5}\right)\right], 129.1\left[\mathrm{C}^{3,5}\left(\mathrm{C}_{6} \mathrm{H}_{5}\right)\right]$, $127.4\left[\mathrm{C}^{4}\left(\mathrm{C}_{6} \mathrm{H}_{5}\right)\right], 123.9(\mathrm{C} \beta), 106.84\left[\mathrm{C}^{4}(\mathrm{pz})\right], 106.78\left[\mathrm{C}^{4}(\mathrm{pz})\right]$, $56.7(\mathrm{C} \gamma), 16.7,15.4,, 12.8,12.7\left(\mathrm{pzCH}_{3}\right)$. Satisfactory elemental microanalytical data were not acquired due to instability.

\section{Synthesis of $\left[\left(\mathrm{Tp}^{*}\right)(\mathrm{OC})_{2} \mathrm{~W} \equiv \mathrm{CC}(\mathrm{SePh})=\mathrm{C}(\mathrm{SePh})-\right.$} $\left.\mathrm{C} \equiv \mathrm{CC} \equiv \mathbf{W}(\mathrm{CO})_{\mathbf{2}}\left(\mathrm{Tp}^{*}\right)\right](6)$. The same procedure for the synthesis of $\mathbf{5}$ above was used. The initially obtained solid was extracted into $\mathrm{CH}_{2} \mathrm{Cl}_{2}$ and chromatographed on a silica gel column, eluting with hexane $/ \mathrm{CH}_{2} \mathrm{Cl}_{2}$ (7:3). A dark red band was collected and the solvent was removed under high vacuum to obtain 6 as red microcrystalline solid. Yield: $12 \mathrm{mg}(11 \%)$. IR (THF): $v_{\mathrm{CC}}=2049$ vw, $v_{\mathrm{CO}}=1982 \mathrm{~s}, 1972 \mathrm{vs}, 1895 \mathrm{vs} \mathrm{cm}^{-1} .{ }^{1} \mathrm{H} \mathrm{NMR}\left(\mathrm{CDCl}_{3}, 25^{\circ} \mathrm{C}\right.$, $400 \mathrm{MHz}): \delta_{\mathrm{H}}=7.54-7.03\left(\mathrm{~m}, 10 \mathrm{H}, \mathrm{C}_{6} \mathrm{H}_{5}\right), 5.79(2 \mathrm{H}) 5.77(2 \mathrm{H})$ $5.70(2 \mathrm{H})(\mathrm{s} \times 3,6 \mathrm{H}, \mathrm{pzH}), 2.44(6 \mathrm{H}), 2.36(6 \mathrm{H}), 2.34(6 \mathrm{H}), 2.32$ $(3 \mathrm{H}), 2.30(3 \mathrm{H}), 2.28(6 \mathrm{H}), 2.01(6 \mathrm{H})\left(\mathrm{s} \times 7,36 \mathrm{H}, \mathrm{pzCH}_{3}-3,5\right)$. ${ }^{13} \mathrm{C}\left\{{ }^{1} \mathrm{H}\right\} \mathrm{NMR}\left(\mathrm{CDCl}_{3}, 25^{\circ} \mathrm{C}, 201 \mathrm{MHz}\right): \delta_{\mathrm{C}}=268.7(\mathrm{~W} \equiv \mathrm{C}), 245.4$ $(\mathrm{W} \equiv \mathrm{C}), 226.9$ (CO, ${ }^{1} J_{\mathrm{WC}}$ could not be resolved due to coincidental resonances), 226.7 ( $\mathrm{CO}, 1{ }^{1} \mathrm{Wc}$ could not be resolved due to coincidental resonances), $152.5\left[\mathrm{C}^{5}(\mathrm{pz})\right], 152.4\left[\mathrm{C}^{5}(\mathrm{pz})\right], 152.3$
$\left[\mathrm{C}^{5}(\mathrm{pz})\right], 151.9\left[\mathrm{C}^{5}(\mathrm{pz})\right], 145.3\left[\mathrm{C}^{3}(\mathrm{pz})\right], 144.8\left[\mathrm{C}^{3}(\mathrm{pz})\right], 144.1$ $\left[\mathrm{C}^{3}(\mathrm{pz})\right], 144.0\left[\mathrm{C}^{3}(\mathrm{pz})\right], 136.3\left(\mathrm{C}_{\mathrm{a}^{\prime}}=\underline{\mathrm{C}}\right), 135.5\left[\mathrm{C}^{2,6}\left(\mathrm{C}_{6} \mathrm{H}_{5}\right)\right], 134.0$ $\left(\mathrm{C}=\mathrm{C}_{\beta^{\prime}}\right), 132.4\left[\mathrm{C}^{2,6}\left(\mathrm{C}_{6} \mathrm{H}_{5}\right)\right], 130.9\left[\mathrm{C}^{1}\left(\mathrm{C}_{6} \mathrm{H}_{5}\right)\right], 130.4\left[\mathrm{C}^{1}\left(\mathrm{C}_{6} \mathrm{H}_{5}\right)\right]$, $129.1\left[\mathrm{C}^{3,5}\left(\mathrm{C}_{6} \mathrm{H}_{5}\right)\right], 128.9\left[\mathrm{C}^{3,5}\left(\mathrm{C}_{6} \mathrm{H}_{5}\right)\right], 128.5\left[\mathrm{C}^{4}\left(\mathrm{C}_{6} \mathrm{H}_{5}\right)\right], 127.1$ $\left[\mathrm{C}^{4}\left(\mathrm{C}_{6} \mathrm{H}_{5}\right)\right], 117.2(\mathrm{C} \equiv \mathrm{C} \alpha), 106.7\left[\mathrm{C}^{4}(\mathrm{pz})\right], 106.6\left[\mathrm{C}^{4}(\mathrm{pz})\right], 106.5$ $\left[\mathrm{C}^{4}(\mathrm{pz})\right], 106.4\left[\mathrm{C}^{4}(\mathrm{pz})\right], 69.0(\mathrm{C} \equiv \mathrm{C} \beta), 16.8,16.2,15.4,15.2,12.8$, 12.7 $\left(\mathrm{pzCH}_{3}\right)$. MS (ESI - high resolution, +ve ion): $\mathrm{m} / \mathrm{z}$ 1461.2005. Calcd. for $\mathrm{C}_{52} \mathrm{H}_{55}{ }^{11} \mathrm{~B}_{2} \mathrm{~N}_{12} \mathrm{O}_{4}{ }^{80} \mathrm{Se}_{2}{ }^{184} \mathrm{~W}_{2}$ : $1461.2005 \quad[\mathrm{M}+\mathrm{H}]^{+}$; 1483.1824 Calcd. for $\mathrm{C}_{52} \mathrm{H}_{55}{ }^{11} \mathrm{~B}_{2} \mathrm{~N}_{12} \mathrm{NaO}_{4}{ }^{80} \mathrm{Se}_{2}{ }^{184} \mathrm{~W}_{2}$ : 1483.1824 $[\mathrm{M}+\mathrm{Na}]^{+}$. Crystals of a benzene monosolvate suitable for diffractometry were grown by slow diffusion of hexane into a solution of the complex in benzene. Crystal data: $\mathrm{C}_{52} \mathrm{H}_{54} \mathrm{~B}_{2} \mathrm{~N}_{12} \mathrm{O}_{4} \mathrm{Se}_{2} \mathrm{~W}_{2} \cdot \mathrm{C}_{6} \mathrm{H}_{6}, M_{\mathrm{r}}=1536.43$, triclinic, space group $P$ 1 (No. 2), $a=10.1236(2), b=15.4789(3), c=19.9039$ (4) $\AA, \alpha$ $=76.1006(17), \beta=81.6539$ (15), $\gamma=84.5006(14)^{\circ}, V=2989.6(10)$ $\AA^{3}, Z=2, D_{\text {calcd. }}=1.707 \mathrm{Mgm}^{-3}, \mu(\mathrm{Cu} \mathrm{K} \alpha) 8.85 \mathrm{~mm}^{-1}$, red plate, $0.12 \times 0.08 \times 0.04 \mathrm{~mm}, 36,975$ measured reflections with $2 \theta_{\max }$ $=144.6^{\circ}, 11,767$ independent reflections, 11,721 adsorptioncorrected data used in $F^{2}$ refinement, 721 parameters, no restraints, $R_{1}=0.037, w R_{2}=0.098$ for 10,564 reflections with I $>2 \sigma(I)$, CCDC 1034121 .

Synthesis of $\left[\left(\mathrm{Tp}^{*}\right)(\mathrm{CO})_{2} \mathrm{~W} \equiv \mathrm{CC}(\mathrm{SeMe})=\mathrm{C}(\mathrm{SeMe}) \mathrm{C} \equiv \mathrm{CC} \equiv \mathbf{W}\right.$ $\left.(\mathrm{CO})_{2}\left(\mathrm{Tp}^{*}\right)\right](\mathbf{8})$ - A mixture of $\left[\mathrm{W}\left(\equiv \mathrm{CC} \equiv \mathrm{CSiMe}_{3}\right)(\mathrm{CO})_{2}\left(\mathrm{Tp}^{*}\right)\right]$ (1: $100 \mathrm{mg}, 0.16 \mathrm{mmol}$ ) and grey selenium (15 mg, $0.19 \mathrm{mg}$-atom) in THF $(20 \mathrm{~mL})$ was treated with a solution of $\left[{ }^{n} \mathrm{Bu}_{4} \mathrm{~N}\right] \mathrm{F}$ in THF $(0.16 \mathrm{~mL}, 1.0 \mathrm{M}, 0.16 \mathrm{mmol})^{\ddagger}$ and left to stir at $\mathrm{r}$. t. for 16 hours to provide a dark yellow orange solution. lodomethane $(0.01$ $\mathrm{mL}, 0.16 \mathrm{mmol}$ ) was added and the mixture stirred for a further 2 hours and then freed of volatiles under reduced pressure. The residue was chromatographed on a silica gel column eluting with a hexane $/ \mathrm{CH}_{2} \mathrm{Cl}_{2}$ gradient $4: 1$ to $1: 1$. The last red mobile fraction with this eluent afforded upon concentration traces of red single crystals. Crystal data: $\mathrm{C}_{42} \mathrm{H}_{50} \mathrm{~B}_{2} \mathrm{~N}_{12} \mathrm{O}_{4} \mathrm{Se}_{2} \mathrm{~W}_{2} \cdot \mathrm{C}_{6} \mathrm{H}_{6}, M_{\mathrm{r}}=$ 1334.18, triclinic, space group $P-1$ (No. 2), $a=11.6869$ (7), $b=$ 13.9225(7), $c=19.4076(16) \AA, \alpha=100.513(5), \beta=104.632(6), \gamma$ $=102.645(5)^{\circ}, V=2885.2(4) \AA^{3}, Z=2, D_{\text {calcd. }}=1.536 \mathrm{Mgm}^{-3}, \mu(\mathrm{Cu}$

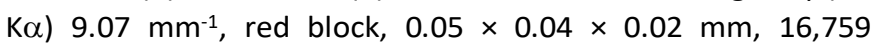
measured reflections with $2 \theta_{\max }=144.5^{\circ}, 10,931$ independent reflections, 11,721 adsorption-corrected data used in $F^{2}$ refinement, 577 parameters, no restraints, $R_{1}=0.088, w R_{2}=$ 0.188 for 10,898 reflections with $I>2 \sigma(I)$, CCDC 1034163 .

\section{Conclusions}

Although the first example of a selenolatopropargylidyne was obtained, the yields were severely compromised due to a range of possible side reactions. Each of these may be traced to the inferred susceptibility of the $\gamma$-carbon of the propargylidyne towards nucleophilic attack by either selenium or carbon-based nucleophiles providing a range of novel selenium appended allylidyne complexes. We are currently exploring the synthetic potential of such processes with respect to other nucleophiles and propargylidynes.

\section{Acknowledgements}


This work was supported by the Australian Research Council (DP170102695).

\section{Notes and references}

\# The reagent [ ${ }^{n} \mathrm{Bu}_{4} \mathrm{~N}$ ] F ('TBAF') was a commercially available 1.0 mol L-1 solution in THF, reported by the supplier (Sigma- Aldrich 216143) to contain $c a 5 \% \mathrm{w} / \mathrm{w}$ water.

1 (a) I. J. Hart, A. F. Hill and F. G. A. Stone, J. Chem. Soc., Dalton Trans., 1989, 2261-2267. (b) Schwenzer, B.; Fischer, H., J. Organomet. Chem. 2003, 667, 16-23. (c) B. Schwenzer, J. Schleu, N. Burzlaff, C. Karl and H. Fischer, J. Organomet. Chem., 2002, 641, 134. (c) E. O. Fischer, H. J. Kalder and F. H. Kohler, J. Organomet. Chem. 1974, 81, C23C27.

2 (a) R. D. Dewhurst, A. F. Hill and M. K. Smith, Angew. Chem., Int. Ed., 2004, 43, 476-478. (b) R. D. Dewhurst, A. F. Hill and A. C. Willis, Dalton Trans., 2009, 3384-3387. (c) R. D. Dewhurst, A. F. Hill and A. C. Willis, Organometallics, 2009, 28, 4735-4740. (d) R. D. Dewhurst, A. F. Hill and A. C. Willis, Dalton Trans., 2009, 3384-3387. (e) R. D. Dewhurst, A. F. Hill and M. K. Smith, Organometallics, 2005, 24, 55765580. (f) R. D. Dewhurst, A. F. Hill, A. D. Rae and A. C. Willis, Organometallics, 2005, 24, 4703-4706. (g) R. D. Dewhurst, A. F. Hill and A. C. Willis, Organometallics, 2005, 24, 3043-3046. (h) R. D. Dewhurst, A. F. Hill and A. C. Willis, Chem. Commun., 2004, 2826-2827. (i) R. D. Dewhurst, A. F. Hill and A. C. Willis, Organometallics, 2004, 23, 5903-5906. (j) R. D. Dewhurst, A. F. Hill and A. C. Willis, Organometallics, 2004, 23, 1646-1648.

3 (a) A. F. Hill and C. M. A. McQueen, Organometallics, 2012, 31, 2482-2485. (b) L. M. Caldwell, A. F. Hill, A. G. Hulkes, C. M. A. McQueen, A. J. P. White and D. J. Williams Organometallics, 2010, 29, 6350-6358. (c) R. B. Bedford, P. J. Dyson, A. F. Hill, A. G. Hulkes and C. J. Yates, Organometallics, 1998, 17, 41174120. (d) M. A. Beswick, P. R. Raithby, A. Steiner, J. C. Vallat, K. L. Verhorevoot and D. S. Wright, J. Chem. Soc., Dalton Trans., 1996, 2183-2184. (b) M. A. Beswick, C. N. Harmer, P. R. Raithby, A. Steiner, M. Tombul and D. S. Wright, J. Organomet. Chem. 1999, 573, 267-271. (e) Y. Sunada, Y. Hayashi, H. Kawaguchi, and K. Tatsumi, Inorg. Chem., 2001, 40, 7072-7078. (f) H. Sugiyama, Y. Hayashi, H. Kawaguchi and K. Tatsumi, Inorg. Chem., 1998, 37, 6773. (g) S. Schaefer, C. Moser, J. J. Tirree, M. Nieger and R. Pietschnig, Inorg. Chem., 2005, 44, 2798-2802. (h) R. Pietschnig, K. Merz and S. Schäfer, Heteroat. Chem., 2005, 16, 169. (i) I. Baxter, A. F. Hill, J. M. Malget, A. J. P. White and D. J. Williams, J. Chem. Soc., Chem. Commun. 1997, 2049-2050.

4 (a) L. M. Caldwell, R. L. Cordiner, A. F. Hill and J. Wagler, Organometallics, 2010, 29, 1526-1529. (b) I. A. Cade, A. F. Hill and C. M. A. McQueen, Organometallics, 2009, 28, 66396641. (c) L. M. Caldwell, A. F. Hill, J. Wagler, and A. C. Willis, Dalton Trans., 2008, 3538-3541. (c) L. M. Caldwell, A. F. Hill, A. D. Rae and A. C. Willis, Organometallics, 2008, 27, 341-345.

5 A. F. Hill, R. A. Manzano, M. Sharma and J. S. Ward Organometallics, 2015, 34, 361-365.

6 A. F. Hill and R. A. Manzano, Dalton Trans., 2018, 47, 14121416.

7 R. L. Cordiner, A. F. Hill and J. Wagler, Organometallics, 2008, 27, 5177-5179.

8 (a) A. Ogawa, N. Takami, M. Sekiguchi, H. Yokoyama, H. Kuniyasu, I. Ryu and N. Sonoda, Chem. Lett., 1991, 12, 2241 2242. (b) M. Tiecco, L. Testaferri, M. Tingoli, D. Chianelli and M. Montanucci, Tetrahedron. Lett., 1984, 25, 4975-4978.

9 D. J. Gulliver, E. G. Hope, W. Levason, S. G. Murray, D. M. Potter and G. M. Marshall, J. Chem. Soc., Perkin Trans. 2, 1984, 429-434.

10 L. M. Caldwell, Adv. Organomet Chem., 2008, 56, 1-94.
11 B. E. Woodworth, P. S. White and J. L. Templeton, J. Am. Chem. Soc. 1997, 119, 828-829.

12 A. V. Moro, C. W. Nogueira, N. B. V. Barbosa, P. H. Menzes, J. B. T. da Rocha and G. Zeni, J. Org. Chem., 2005, 70, 52575268.

13 Reviews: (a) C. Coletti, A. Marrone and N. Re, Acc. Chem. Res., 2012, 45, 139-149. (b) V. Cadierno and S. E. Garcia-Garrido, Topics Organomet. Chem., 2010, 30, 219-252. (c) V. Cadierno, S. E. Garcia-Garrido, Topics Organomet. Chem., 2010, 30,151218. (d) V. Cadierno and J. Gimeno, Chem. Rev., 2009, 109, 3512-3560.

14 T. G. Black and M. V. Krishna, J. Org. Chem., 1988, 53, 25332536.

15 H. Sun and S. G. DiMagno, J. Am. Chem. Soc., 2005, 127, 20502051.

16 D. J. Cook, A. F. Hill and D. J. Wilson, Dalton Trans. 1998, 11711174.

17 P. A. Grieco, S. Gilman and M. Nishizawa, J. Org. Chem. 1976, 41, 1485-1486. 
Table of Contents Graphic

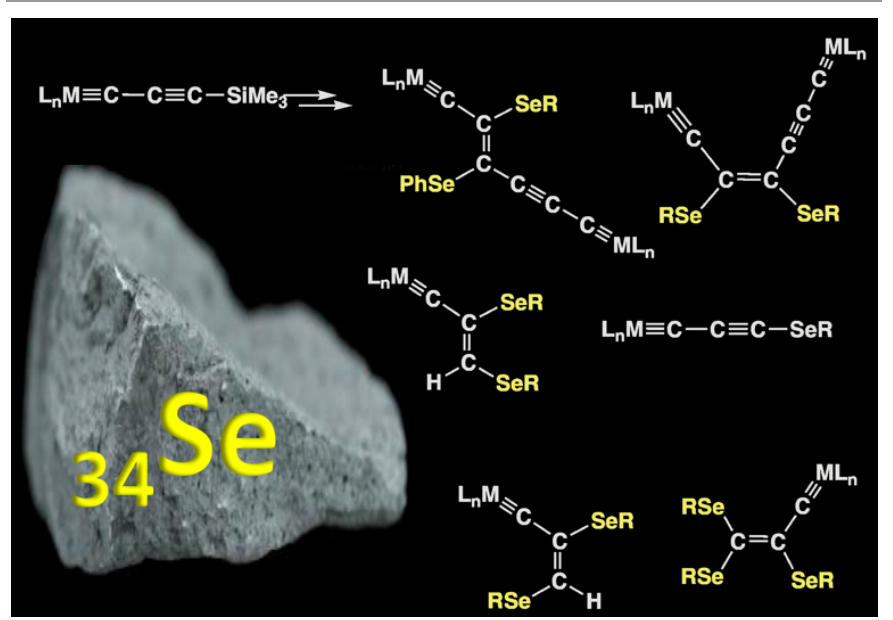

